University of Nebraska - Lincoln

DigitalCommons@University of Nebraska - Lincoln

1974

Polypodium sp. (Coelenterata) Found in North American Sturgeon

Glenn L. Hoffman

US Fish and Wildlife Service

Follow this and additional works at: https://digitalcommons.unl.edu/usfwspubs

Part of the Aquaculture and Fisheries Commons

Hoffman, Glenn L., "Polypodium sp. (Coelenterata) Found in North American Sturgeon" (1974). US Fish \& Wildlife Publications. 110.

https://digitalcommons.unl.edu/usfwspubs/110

This Article is brought to you for free and open access by the US Fish \& Wildlife Service at DigitalCommons@University of Nebraska - Lincoln. It has been accepted for inclusion in US Fish \& Wildlife Publications by an authorized administrator of DigitalCommons@University of Nebraska - Lincoln. 


\section{Polypodium Sp. (Coelenterata) Found in North American Sturgeon}

On 27 May 1970, Mason Shouder, Michigan Fisheries Biologist, discovered some abnormal eggs in a ripe sturgeon, Acipenser fulvescens. The fish were taken from the Black River near Cheboygan, Michigan, which is barricaded from Lake Huron by a dam built in the 1920's. Normal ripe eggs were black spheres; the abnormal ones were enlarged and grayish (Fig. 1). About $20 \%$ of the eggs were affected and attached to the wall of the uterus in saclike structures. The ovary was also abnormal, being flaccid. In May 1973, a single infected egg was found in vodka-pre- served eggs from a ripe sturgeon from the same locality; only one of 1,391 eggs $(0.07 \%)$ was found infected.

The abnormal eggs contain the mature stolon stage of Polypodium sp. (Fig. 2). The stolon is a white elongate structure, $1.3 \mathrm{~mm}$ in diameter, and has many fingerlike tentacles 0.87 to $1.2 \mathrm{~mm}$ long by 0.17 to $0.087 \mathrm{~mm}$ diameter. No intact stolons were available for length measurement.

Polypodium hydriforme Ussov, 1885 (Figs. 3-5) has been reported from Acipenser spp. from some of the major rivers of the USSR

Figures 1, 2. A coelenterate parasite of sturgeon eggs from Michigan. 1. Enlarged gray eggs on the right contain mature stolons of Polypodium sp. Normal black eggs are on the left. 2. Eggs infected with Polypodium sp. Egg at lower left is still intact; egg at upper right has been torn to release fragments of the parasite.

Figures 3, 4. Polypodium hydriforme from Russian Acipenser ruthenus (Raikova, 1958, Zool. Zhurnal 37: 345-358). 3. Sterlet eggs. Enlarged gray ones contain stolons. 4. Mature stolon. 


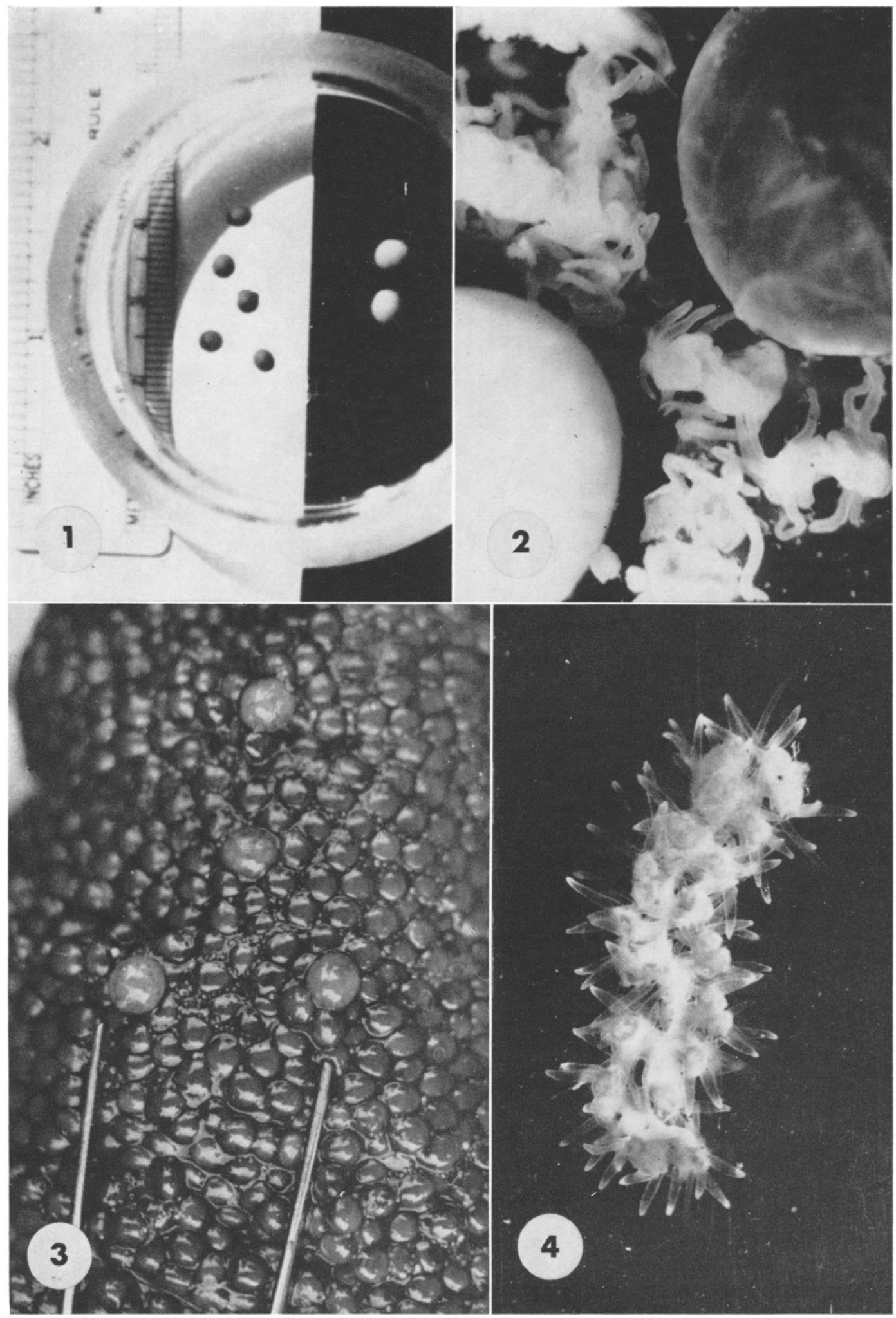




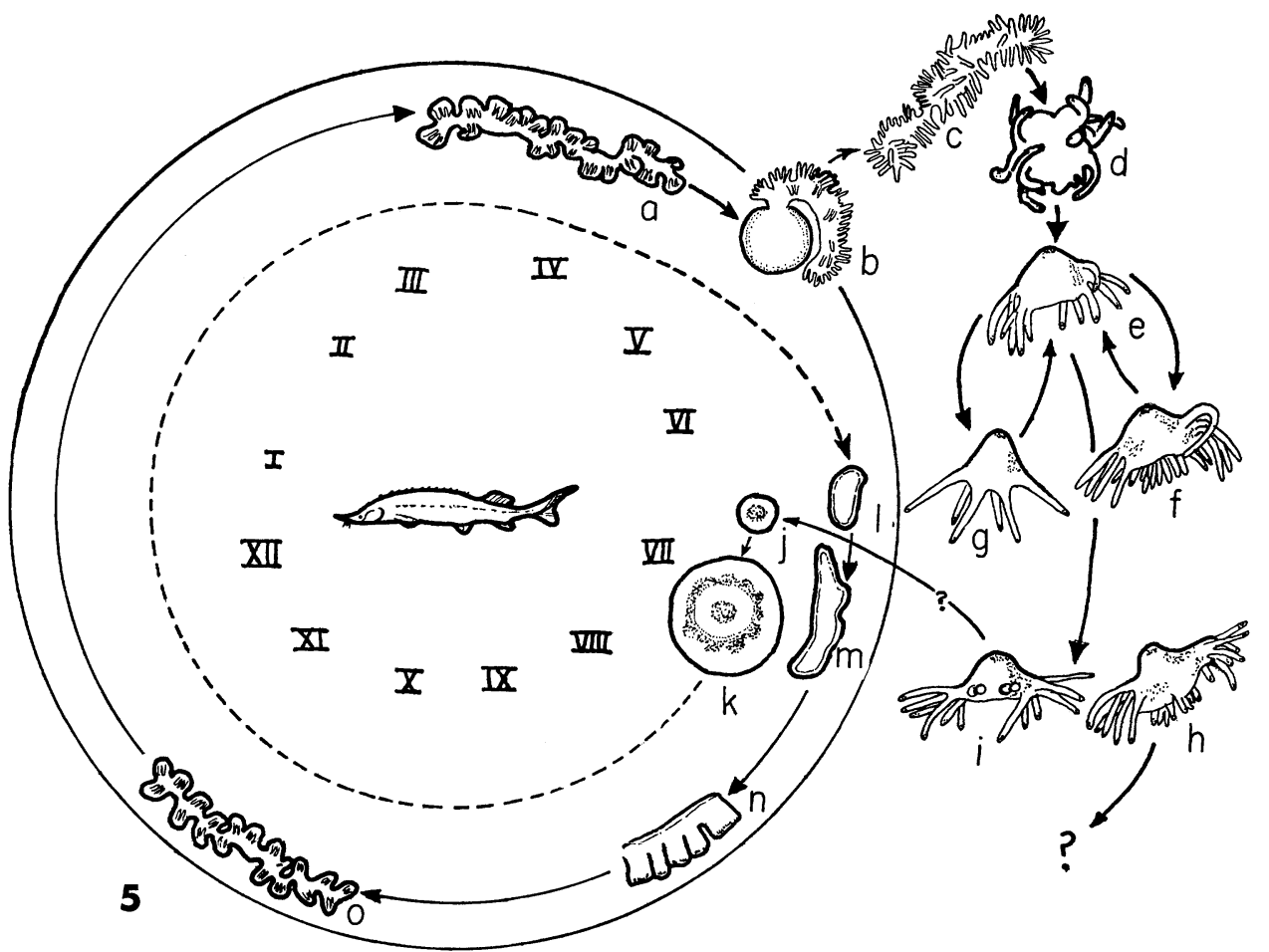

Figure 5. Life cycle of Soviet Polypodium hydriforme. Roman numerals represent months. (a) Mature stolon with internal tentacles from egg before spawning. (b) Stolon with external tentacles emerging from egg at time of spawning. (c) Free stolon. (d-i) Stolon becomes polyp which may divide; route back to fish is unknown. ( $\mathrm{j}-\mathrm{k}$ ) Early embryonic stages in egg. (l-n) Juvenile stolons. (o) Stolon with internal tentacles. (Modified from Raikova, 1958, Zool. Zhurnal 37: 345-358.)

(Raikova, in Bykhovskaya-Pavlovskaya et al., 1962, Key to Parasites of Freshwater Fish of the USSR., Zool. Inst., Acad. Sci. USSR; Eng. transl. No. TT64-11040, O.T.S., U. S. Dept. Commerce, Washington, D. C., 1964, 919 p.). It has also been reported from the Danube River in Rumania [Bogatu, 1961, Un car de infesatie cu Polypodium hydriforme Ussov, 1885, la cega (Acipenser ruthenus G) din Danăre. Bull. Inst. Cercetări Si proiectǎri piscicola 20 (11) : 54-59].

This is the first North American record of
Polypodium sp. If more material becomes available, species determination will be attempted. With the current price of caviar $\$ 100 / 1 b$ this may be a very important fish parasite. We would appreciate receiving additional material.

G. L. Hoffman, Eastern Fish Disease Laboratory, Kearneysville, West Virginia 25430; E. V. Raikova, Inst. Cytol., Acad. Sci., Leningrad, USSR; and W. G. Yoder, Michigan Department of Natural Resources, Grayling Research Station, Grayling, Michigan 49738 